\title{
Carbon sources supporting benthic mineralization in mangrove and adjacent seagrass sediments (Gazi Bay, Kenya)
}

\author{
S. Bouillon ${ }^{1}$, T. Moens ${ }^{2}$, and F. Dehairs ${ }^{1}$ \\ ${ }^{1}$ Department of Analytical and Environmental Chemistry, Mangrove Management Group, Vrije Universiteit Brussel, \\ Pleinlaan 2, B-1050 Brussels, Belgium \\ ${ }^{2}$ Biology Department, Marine Biology Section, Ghent University, Krijgslaan 281/Sterre S8, B-9000 Gent, Belgium
}

Received: 14 July 2004 - Published in Biogeosciences Discussions: 6 August 2004

Revised: 12 October 2004 - Accepted: 15 October 2004 - Published: 28 October 2004

\begin{abstract}
The origin of carbon substrates used by in situ sedimentary bacterial communities was investigated in an intertidal mangrove ecosystem and in adjacent seagrass beds in Gazi bay (Kenya) by $\delta^{13} \mathrm{C}$ analysis of bacteria-specific PLFA (phospholipid fatty acids) and bulk organic carbon. Export of mangrove-derived organic matter to the adjacent seagrasscovered bay was evident from sedimentary total organic carbon (TOC) and $\delta^{13} \mathrm{C}_{\mathrm{TOC}}$ data. PLFA $\delta^{13} \mathrm{C}$ data indicate that the substrate used by bacterial communities varied strongly and that exported mangrove carbon was a significant source for bacteria in the adjacent seagrass beds. Within the intertidal mangrove forest, bacterial PLFA at the surface layer $(0-1 \mathrm{~cm})$ typically showed more enriched $\delta^{13} \mathrm{C}$ values than deeper (up to $10 \mathrm{~cm}$ ) sediment layers, suggesting a contribution from microphytobenthos and/or inwelled seagrass material.

Under the simplifying assumption that seagrasses and mangroves are the dominant potential end-members, the estimated contribution of mangrove-derived carbon to benthic mineralization in the seagrass beds (16-74\%) corresponds fairly well to the estimated contribution of mangrove $\mathrm{C}$ to the sedimentary organic matter pool (21-71\%) across different seagrass sites. Based on the results of this study and a compilation of literature data, we suggest that trapping of allochtonous $\mathrm{C}$ is a common feature in seagrass beds and often represents a significant source of $\mathrm{C}$ for sediment bacteria - both in cases where seagrass $\mathrm{C}$ dominates the sediment TOC pool and in cases where external inputs are significant. Hence, it is likely that data on community respiration rates systematically overestimate the role of in situ mineralization as a fate of seagrass production.
\end{abstract}

Correspondence to: S. Bouillon

(steven.bouillon@vub.ac.be)

\section{Introduction}

Estuaries and other coastal ecosystems form a significant component of the global carbon balance, as intense processing of organic matter -originating from fluvial inputs, local production, or lateral inputs from marshes and mangrovestakes place (e.g. Gattuso et al., 1998). There are still large uncertainties in the overall magnitude of the various components of the carbon balance in the coastal zone - in particular for the tropics where $>60 \%$ of the global riverine inputs of particulate and dissolved organic carbon (POC and DOC) are thought to occur (Ludwig et al., 1996) but for which relatively few data are available. Besides these quantitative aspects, it has to be considered that multiple sources of organic matter reach estuarine and coastal systems, and that source characterization of the mineralized material is therefore an essential part of our understanding of their biogeochemical functioning.

Mangrove forests and tropical seagrass beds are both very productive systems and a major fate of their primary production is in situ decomposition (on average 40.1 and $50.3 \%$, respectively, according to Duarte and Cebrián, 1996). Seagrass beds influence water flow patterns resulting in increased sedimentation or trapping of suspended matter and reducing the degree of sediment resuspension. On the other hand, a significant fraction of seagrass production may also be exported out of the system (a literature compilation by Duarte and Cebrián, 1996 suggests on average $\sim 25 \%$ of the primary production). The ideas of leaf litter export from seagrass beds and trapping of organic/suspended material are not mutually exclusive: in the estuarine mangrove-seagrass system of Gazi Bay (Kenya), for example, both processes have been evidenced (Hemminga et al., 1994; Slim et al., 1996a) and hence, a bidirectional exchange of organic matter is known to occur.

If utilization of carbon imported from outside the ecosystem boundaries or from other primary producers within the 


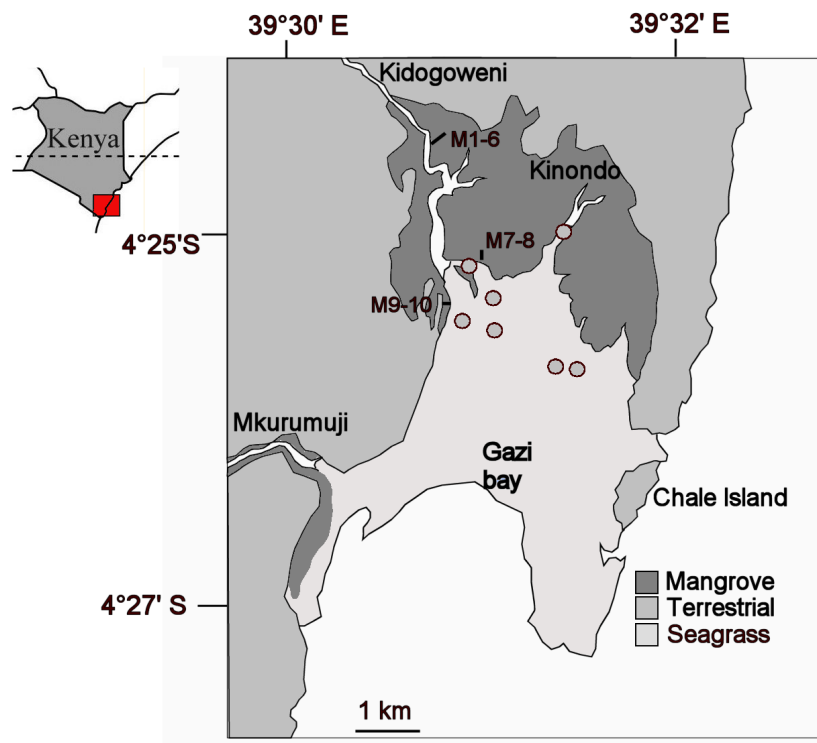

Fig. 1. Location of the study area and sampling sites. Short lines show the transects where mangrove cores (indicated as M1 to M10) were taken, seagrass sampling sites are shown as grey circles. See legend for the delineation of the mangrove and seagrass habitats.

system is a common feature in seagrass beds, this may have important consequences for budgeting studies. The current estimates of the fate of seagrass production (compiled e.g. in Duarte and Cebrián, 1996; Cebrián, 2002) are typically based on quantitative process measurements (e.g. communtiy respiration), and since such measurements inherently do not include a characterization of the sources of $\mathrm{C}$ fuelling mineralization, they may represent a biased view of the importance of mineralization as a fate of seagrass carbon. Recent analytical advances have made it possible to study the origin of the carbon supporting bacterial communities by comparing stable isotope signatures of bacterial biomarkers with those of potential substrates. For intertidal salt marshes (Boschker et al., 1999) and mangroves (Bouillon et al., 2004), this technique has shown that the origin of the organic matter sustaining bacterial production is diverse and varies both between and within such ecosystems. In some cases, production by local vascular plants appears to be the dominant source for benthic mineralization, but carbon imported from the aquatic environment and local production by microphytobenthos can overtake this role in other sites (Boschker et al., 1999; Bouillon et al., 2004). For seagrass beds, several studies using phospholipid fatty acids (PLFA) stable isotope techniques have suggested either that seagrass-derived carbon was of limited importance to local bacterial communities (Boschker et al., 2000 for Zostera marina and Z. noltii), or that seagrasses were a major contributor to carbon assimilation by bacterial communities (Holmer et al., 2001; Jones et al., 2003 for Thalassia hemprichii and Cymodocea rotundata and for T. testudinum, respectively). A recent study by Holmer et

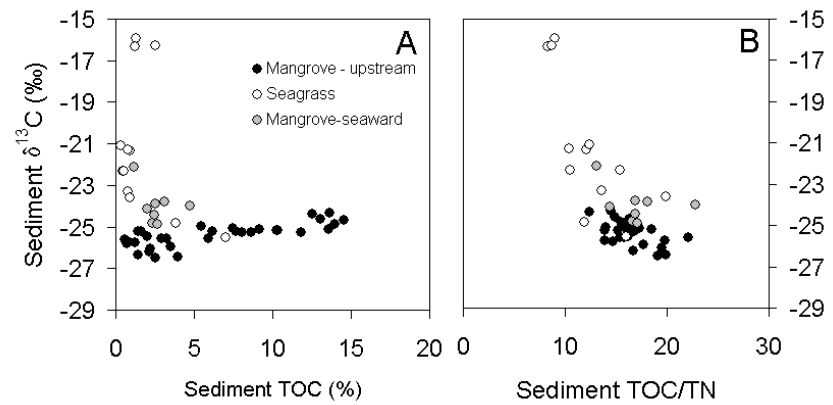

Fig. 2. (A) Sediment organic carbon content (as \% dry weight) versus the carbon isotope composition of sedimentary organic carbon, and (B) Sediment TOC/TN ratios versus the carbon isotope composition of sedimentary organic carbon. Open symbols: data from seagrass sediments; grey symbols: data from mangrove sediments in the seaward Sonneratia site; black symbols: data from the more inland mangrove sites.

al. (2004) in Mediterranean seagrass meadows indicated that benthic mineralization was predominantly sustained by seagrass inputs in pristine systems, but relied significantly on external $\mathrm{C}$ sources in anthropogenically impacted sites.

In this study, we sampled sediments at various sites within the intertidal mangrove habitat as well as in adjacent dense seagrass beds in Gazi bay (Kenya). Export of mangrovederived carbon and subsequent trapping of this material in these seagrass beds has been previously documented (e.g. Hemminga et al., 1994), as well as inwelling of seagrassderived organic matter into the mangrove areas (Slim et al., 1996a). Thus, this site offers an excellent case to determine to which extent bacterial communities exploit these two sources of vascular plant material in relation to their relative availability in the sedimentary organic matter pool. Based on these results and similar datasets from the literature, we suggest that allochtonous (i.e. non-seagrass derived) carbon may represent a significant fraction of the substrate used in benthic mineralization, and hence, that respiration rate measurements might frequently overestimate the role of mineralization in the overall seagrass $\mathrm{C}$ budget.

\section{Materials and methods}

\subsection{Study site and sampling methods}

Gazi bay $\left(39^{\circ} 30^{\prime} \mathrm{E}, 4 .^{\circ} 22^{\prime} \mathrm{S}\right.$, see Fig. 1) is located $\sim 50 \mathrm{~km}$ south of Mombasa, and covers a total area of $\sim 10 \mathrm{~km}^{2}$, with an additional 6 to $7 \mathrm{~km}^{2}$ covered by mangroves, mostly Rhizophora mucronata, Sonneratia alba, Ceriops tagal, Bruguiera gymnorrhiza, Avicennia marina, and Xylocarpus granatum. Seagrasses (mainly Thalassodendron ciliatum) form dense beds in the lower parts of Kinondo creek and cover $\sim 70 \%$ of the bay area (Coppejans et al., 1992). The bay opens into the Indian Ocean through a relatively wide but 


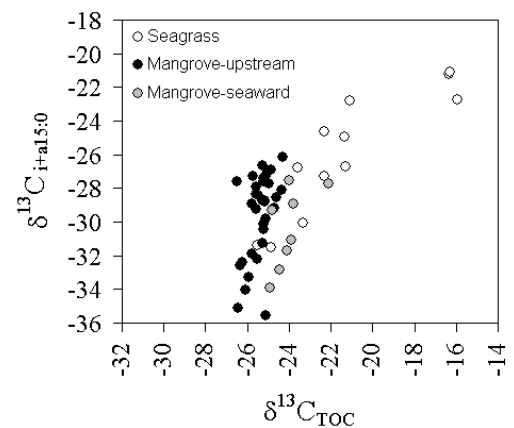

Fig. 3. $\delta^{13} \mathrm{C}$ of sediment organic carbon versus $\delta^{13} \mathrm{C}$ of $\mathrm{i}+\mathrm{a} 15: 0$. Symbols as in Fig. 2.

shallow entrance in the southern part. The upper region of the bay receives freshwater through the Kidogoweni river which traverses the mangroves. Spring tidal range in Gazi bay is reported to be $3.2 \mathrm{~m}$ (Kitheka, 1997). T. ciliatum production in the bay has been estimated to range between 710 and $1365 \mathrm{~g} \mathrm{C} \mathrm{m}^{-2} \mathrm{y}^{-1}$ (Hemminga et al., 1995); litterfall data for C. tagal, R. mucronata, and A. marina correspond to litter production of 164,412 , and $236 \mathrm{~g} \mathrm{C} \mathrm{m}^{-2} \mathrm{y}^{-1}$, respectively (Slim et al., 1996b; Ochieng and Erftenmeijer, 2002).

In the intertidal mangrove zone, 10 sediment cores were collected with a PVC corer and were immediately cut into $0-1 \mathrm{~cm}, 1-2 \mathrm{~cm}, 2-4 \mathrm{~cm}$ and $4-10 \mathrm{~cm}$ subsections. At each site, leaves from the dominant mangrove trees were collected and dried at $60^{\circ} \mathrm{C}$ for at least $48 \mathrm{~h}$ for later stable isotope analysis. In the seagrass beds, cores were similarly sampled at 7 locations at various distances from the mangrove forest edge, either at low tide or by snorkeling (see Fig. 1). Due to the sandy nature of these sediments, it was often impossible to make further sections - consequently samples from the seagrass beds typically cover the first $\sim 6 \mathrm{~cm}$. Most seagrass stations were sampled and analyzed in duplicate (note, therefore, that Figs. 2, 3, 5, 6, and 7 show more than 7 data points from the seagrass beds). Samples were transported to the fieldlab in a cool box and stored frozen. Samples were later freeze-dried before further processing. A minimum of 10 leaves from different shoots of the dominant seagrass vegetation was sampled at each site. These were thoroughly washed and scraped to remove the majority of epiphytes, frozen and later freeze-dried.

\subsection{Analytical procedures}

Freeze-dried core subsections were homogenized using a mortar and pestle. Subsamples were taken for elemental (TOC/TN, atom) and bulk stable isotope composition. These were weighed into silver cups and acidified in situ with dilute $(5 \%) \mathrm{HCl}$ to remove carbonates. Concentrations of organic carbon and total nitrogen (expressed as \%, dry weight basis), and TOC/TN ratios were determined using a ThermoFinnigan Flash1112 elemental analyzer using acetanilide
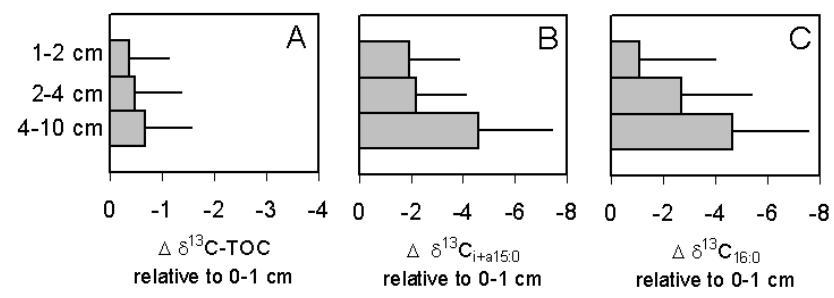

Fig. 4. Average difference in $\delta^{13} \mathrm{C}$ signatures of (A) total sediment organic carbon, (B) i+a15:0, and (C) 16:0 between the surface section $(0-1 \mathrm{~cm})$ and depth sections from all mangrove cores. Error bars indicate 1 s.d. Note the different scales of the X-axis between (A), (B) and (C)

for calibration. $\delta^{13} \mathrm{C}$ analysis of TOC was measured on the same samples after the combustion gases were transferred to a ThermoFinnigan delta + XL via a Conflo III interface, with a typical reproducibility better than $\pm 0.15 \%$. $\delta^{13} \mathrm{C}$ analysis of seagrass and mangrove tissues followed the same procedure, although mangrove leaves were not treated with $\mathrm{HCl}$ since no carbonate is expected to be present.

Extraction and derivatization of PLFA was performed using a modified Bligh and Dyer extraction, silica gel partitioning, and mild alkaline transmethylation as described earlier (Bouillon et al., 2004). $\delta^{13} \mathrm{C}$ values of the resulting FAMEs (fatty acid methyl esters) were determined on a HP6890 GC coupled to a ThermoFinnigan delta+XL via a GC/C III interface. All samples were run in splitless mode, using a HP-5 column $(30 \mathrm{~m}, 0.32 \mathrm{~mm}$ ID) and a He flow rate of $2 \mathrm{~mL} / \mathrm{min}$. The $\delta^{13} \mathrm{C}$ values of PLFAs are corrected for the addition of the methyl group by simple mass balance. Reproducibility of the PLFA $\delta^{13} \mathrm{C}$ analysis on well resolved standards is typically $0.3 \%$ or better, but usually lower $( \pm 0.6 \%$ ) for major PLFA from natural samples. All stable isotope ratios are expressed relative to the conventional standard (VPDB limestone) as $\delta$ values, defined as $\delta^{13} \mathrm{C}=$ $1000 \times\left(X_{\text {sample }}-X_{\text {standard }}\right) / X_{\text {standard }}$ where $X={ }^{13} \mathrm{C} /{ }^{12} \mathrm{C}$. Fatty acid notation contains the number of $\mathrm{C}$ atoms, followed by a colon and the number of double bonds. The position of the first double bond (from the aliphatic end of the fatty acid) is indicated after the " $\omega$ ". Prefixes "i" (iso) and "a" (anteiso) refer to the location of a methyl group 1 or 2 carbons from the aliphatic end, respectively. Methyl branches in other positions are indicated by the prefix "Me" (e.g. 10 Me 16:0), and the "cy" prefix indicates a cyclopropane fatty acid.

\section{Results}

$\delta^{13} \mathrm{C}$ values of seagrass tissues ranged between -18.6 and $-10.7 \%$ o (Table 1), consistent with earlier data from this site (Hemminga et al., 1994). Mangrove leaf tissues from the various sites showed average $\delta^{13} \mathrm{C}$ values between -31.2 and $-26.8 \%$ (Table 1). Sediment TOC values ranged between 0.3 and $7.0 \%$ in the seagrass sites, and between 0.6 
Table 1. Summary of elemental (\% TOC, TOC/TN) composition of sediments, and $\delta^{13} \mathrm{C}$ values of sediment organic carbon, plant biomass (seagrasses, mangroves), and bacterial PLFA in the mangroves and seagrass beds of Gazi Bay, Kenya. Note that plant $\delta^{13} \mathrm{C}$ values for seagrasses refer to pooled samples of at least 10 shoots, whereas for mangroves individual leaves of different species were analysed.

\begin{tabular}{|c|c|c|}
\hline & Seagrass beds & Mangroves \\
\hline$\%$ TOC (range) & 0.3 to $7.0 \%$ & 0.6 to $14.6 \%$ \\
\hline$\%$ TOC, average & \pm 1 s.d. $1.7 \pm 1.9 \%$ & $5.6 \pm 4.5 \%$ \\
\hline TOC/TN (range) & 8.3 to 19.9 & 12.4 to 22.8 \\
\hline $\mathrm{TOC} / \mathrm{TN}$, average & \pm 1 s.d. $12.4 \pm 3.4$ & $16.7 \pm 2.2$ \\
\hline$\delta^{13} \mathrm{C}_{\mathrm{TOC}}$ (range) & -25.5 to $-16.0 \%$ & -26.5 to $-22.1 \%$ o \\
\hline$\delta^{13} \mathrm{C}_{\mathrm{TOC}}$ (average \pm 1 s.d.) & $-21.2 \pm 3.3 \%$ & $-25.1 \pm 0.8 \%$ \\
\hline$\delta^{13} \mathrm{C}_{\mathrm{plant}}($ range $)$ & -18.6 to $-10.7 \%$ o & -31.2 to $-26.8 \%$ o \\
\hline$\delta^{13} \mathrm{C}_{\text {plant }}$ (average \pm 1 s.d.) & $-14.3 \pm 2.9 \%$ & $-28.7 \pm 1.7 \%$ \\
\hline$\delta^{13} \mathrm{C}_{\mathrm{i}+\mathrm{a} 15: 0}$ (range) & -31.5 to $-21.1 \%$ o & -35.6 to $-26.1 \%$ o \\
\hline$\delta^{13} \mathrm{C}_{\mathrm{i}+\mathrm{a} 15: 0}$ (average \pm 1 s.d.) & $-25.9 \pm 3.7 \%$ & $-29.7 \pm 2.5 \%$ \\
\hline
\end{tabular}
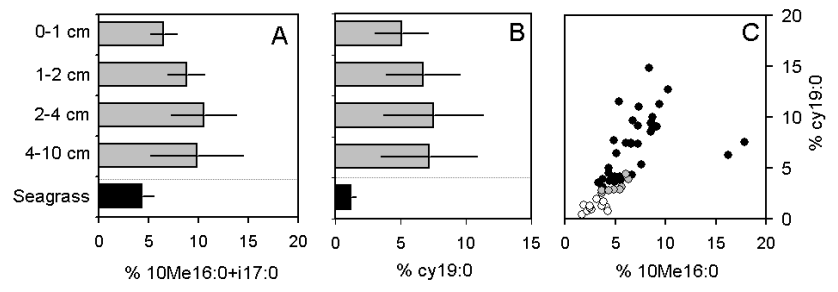

Fig. 5. Distribution of the $\%$ abundance of (A) $10 \mathrm{Me} 16: 0+\mathrm{i} 17: 0$, and (B) cy 19:0 in different depth sections of mangrove cores and in seagrass sediments, and (C) the relative abundance of cy 19:0 versus the relative abundance of the sulfate reducer marker 10Me16:0. In (A) and (B), average \pm 1 s.d. are shown. In (C), figures are as in Fig. 2.

and $14.6 \%$ in the mangrove sites (Table 1). The highest TOC values for seagrass sites (3.8 and 7.0\%) were recorded in Kinondo creek, a seagrass-covered tidal creek which dissects the northern part of the mangrove forest. TOC/TN values were on average lower in the seagrass sites (8.3-19.9) than in the mangrove sites (12.4-22.8) - see Table 1 and Fig. 2. No consistent depthwise trends could be detected in the TOC or TOC/TN data. $\delta^{13} \mathrm{C}$ values for sediment organic matter in the mangrove sites (Table 1) were fairly homogenous, ranging between -26.5 and $-24.3 \%$ for the landward sites and between -24.9 and $-22.1 \%$ for the seaward Sonneratia site.

The $\delta^{13} \mathrm{C}$ of selected bacterial PLFA show a wide range of values. $\delta^{13} \mathrm{C}$ of the often used iso- and anteiso-branched i+a15:0 (combined in view of the availability of data on the degree of fractionation between the substrate and PLFA, i.e. $-5.6 \pm 1.8 \%$ o, Boschker et al., 1999) range from -35.6 to $-26.1 \%$ in the mangrove cores, and between -31.5 and $-21.1 \%$ in the seagrass sediments. There is a clear overall covariation between $\delta^{13} \mathrm{C}$ values of TOC and those of most bacterial PLFA (e.g. Fig. 3 for i+a15:0). Depthwise, there was a significant (two-tailed paired t-test, $\mathrm{p}<0.05$ ) gradual decrease in PLFA- $\delta^{13} \mathrm{C}$ (e.g. Fig. 4 for i+a15:0 and 16:0)
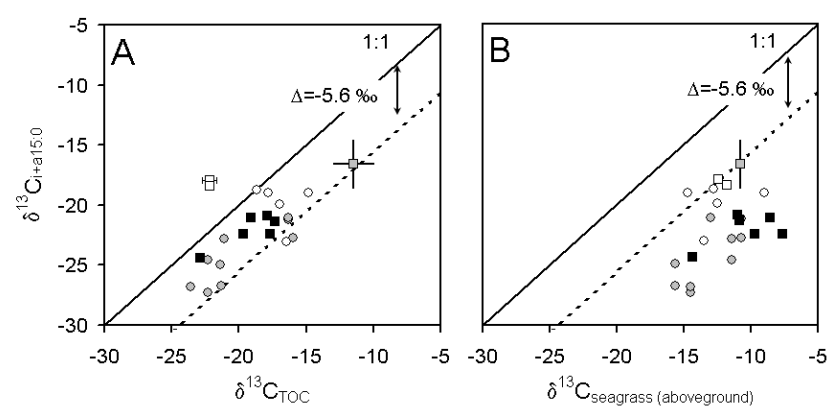

Fig. 6. $\delta^{13} \mathrm{C}$ values of $\mathrm{i}+\mathrm{a} 15$ :0 versus (A) $\delta^{13} \mathrm{C}$ of bulk sediment organic carbon, and (B) $\delta^{13} \mathrm{C}$ of (aboveground) seagrass tissues. Grey circles: data from this study; open squares: data from Holmer et al. (2001); black squares: data from Boschker et al. (2000), grey square: data from Jones et al. (2003), and open circles: data from Holmer et al. (2004). The full line represents the 1:1 line, the dotted line uses the average fractionation value determined by Boschker et al. (1999), i.e. $-5.6 \pm 1.8 \%$, to indicate where $\delta^{13} C_{i+a 15: 0}$ is expected when the substrate on the $\mathrm{X}$-axis is the sole $\mathrm{C}$ source. Data available on request.

which typically averages $\sim 4 \%$ o between the surface sediment $(0-1 \mathrm{~cm})$ and the $4-10 \mathrm{~cm}$ section. In contrast, there was on average only a slight depthwise depletion in $\delta^{13} \mathrm{C}_{\mathrm{TOC}}$, with an average difference of $-0.67 \pm 0.91 \%$ o between the surface layer $(0-1 \mathrm{~cm})$ and the deepest section considered (4$10 \mathrm{~cm}$, Fig. $4 \mathrm{~A}, \mathrm{p}=0.05$ for surface versus $4-10 \mathrm{~cm}$ section, $\mathrm{p}=0.01$ for $1-2 \mathrm{~cm}$ versus $4-10 \mathrm{~cm}$ section).

\section{Discussion}

\subsection{Composition of mangrove and seagrass sediments}

The $\delta^{13} \mathrm{C}$ signatures of mangrove sediment TOC did not vary much over the different sites sampled, typically ranging between -26.5 and $-24.3 \%$, except in the seaward Sonneratia 


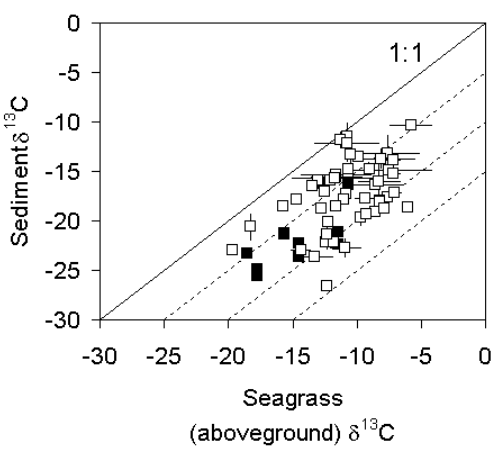

Fig. 7. Compilation of data from this study (black symbols, $n=12$ ) and literature data (open symbols, $\mathrm{n}=49$ ) on seagrass (aboveground) $\delta^{13} \mathrm{C}$ and corresponding sediment $\delta^{13} \mathrm{C}$ data. The $1: 1$ line shows the expected sediment $\delta^{13} \mathrm{C}$ in case seagrasses were the only contributors to the sediment TOC pool. Other isolines represent an offset of $-5 \%$ o, $-10 \%$ and $-15 \%$, respectively. Error bars indicate 1 s.d. Literature data sources: Barrón et al. (2004), Boschker et al. (2000), Dauby (1989), Dauby et al. (1998), Fry (1984), Fry et al. (1977, 1982, 1983), Gacia et al. (2002), Harrigan et al. (1989), Holmer et al. (2001, 2004), Jones et al. (2003), Kennedy et al. (2001), Kennedy et al. (2004), Kharlamenko et al. (2001), Kieckbusch et al. (2004), Nagelkerken and van der Velde (2004), Vizzini et al. (2002), and Vizzini and Mazzola (2004). Note: (i) the data presented in Harrigan et al. (1989) and Kieckbusch et al. (2004), an average $\delta^{13} \mathrm{C}$ was taken for three co-occurring seagrass species; (ii) in the Kharlamenko et al. (2001) dataset, seagrass $\delta^{13} \mathrm{C}$ values for green, brown and dead leaves were averaged; (iii) sediment $\delta^{13} \mathrm{C}$ values for Dauby et al. (1998) refer to the "aerobic zone" data only, and (iv) data from Vizzini and Mazzola (2004) represent an average value for data from four different seasons. Data available on request.

sediments where distinctly more enriched values were found ( -24.9 to $-22.1 \%$, see Fig. 2). Considering the proximity of the Sonneratia site to the seagrass beds and the observation that seagrass fragments were common in the mangroves here, it is likely that imported seagrass contributed significantly to the TOC pool in this area. In the more upstream mangrove sediments, $\delta^{13} \mathrm{C}$ values are typically $\sim 2 \%$ o more enriched than mangrove leaf biomass - a commonly observed offset between aboveground vegetation and soil/sediments (e.g. see Ehleringer et al., 2000). These values, coinciding with relatively high TOC/TN ratios $(16.7 \pm 2.0)$ suggest that decomposed mangrove material makes up most of the sediment TOC (Bouillon et al., 2003). Neither TOC or TOC/TN ratios showed consistent or significant depthwise variations (data not shown) - in contrast, $\delta^{13} \mathrm{C}$ values decreased slightly but significantly ( $-0.7 \pm 0.9 \%$ o between the surface layer and the $4-10 \mathrm{~cm}$ section, Fig. 3A).

Seagrass $\delta^{13} \mathrm{C}$ signatures were distinctly higher than those of mangroves, but were highly variable, consistent with earlier data in this area (Hemminga et al., 1994). This variability is thought to be caused by the large variations in $\delta^{13} \mathrm{C}$ of dissolved inorganic carbon (DIC) in the bay (e.g. in
Kinondo creek and the seagrass beds in the bay, $\delta^{13} \mathrm{C}_{\mathrm{DIC}}$ ranged between -8.4 and $+1.7 \%$ o during the sampling period, own unpublished data). The $\delta^{13} \mathrm{C}$ of seagrass sediment TOC was overall not well correlated with seagrass $\delta^{13} \mathrm{C}$ values $\left(\mathrm{R}^{2}=0.55\right.$, figure not shown). As a first approximation and using mangroves $(-28.7 \pm 1.7 \% o, n=36)$ and seagrasses (site-specific $\delta^{13} \mathrm{C}$ ) as sole end-members, we calculate that exported mangrove carbon comprises $21-70 \%$ of the sediment organic $\mathrm{C}$ pool in the seagrass sediments. We must stress here that these simple calculations do not take into account possible phytoplankton inputs, but since $\mathrm{POC} / \mathrm{Chl}$ a ratios in the bay area during the sampling period were high (764 $\pm 259, n=30$, Bouillon and Borges, unpublished data) we have assumed that live phytoplankton biomass makes up only a very small part of the particulate $\mathrm{C}$ pool. If (e.g. detrital) phytoplankton inputs would be important, inclusion of this source into our calculations would not be straightforward in view of the expected variability in their $\delta^{13} \mathrm{C}$ signatures (based on the observed $\delta^{13} \mathrm{C}_{\text {DIC }}$ trends, see above).

\subsection{PLFA biomarker profiles}

Although an in-depth analysis of the PLFA concentration profiles is beyond the scope of this manuscript, it is worth mentioning a few marked trends in the biomarker data for certain functional groups. First, there was a significant depthwise increase in the relative abundance of PLFA typically considered as markers for sulfate-reducing (SR) bacteria (10Me16:0 + i17:0, see Fig. 5A, paired t-test results in $\mathrm{p}=0.02$ for $0-1 \mathrm{~cm}$ section versus $4-10 \mathrm{~cm}$, and $\mathrm{p}<0.001$ for $0-1 \mathrm{~cm}$ versus $2-4 \mathrm{~cm}$ sections). Such a trend can be expected in view of the anoxic conditions required for sulfate reduction - although it is now acknowledged that sulfate reduction may also occur under oxic conditions (Canfield and Des Marais, 1991). Secondly, the relative abundance of these SR markers was significantly lower in the seagrass sites when compared to mangrove sediments (Fig. 5A) - suggesting that sulfate reduction is a much less important diagenetic pathway in seagrass compared to mangrove sediments, at least in this particular setting. Another PLFA of interest and showing a similar depthwise increase in the mangrove cores (Fig. 5B) is cy 19:0 which we reported earlier to occur in relatively high abundances in mangrove sediments from India and Sri Lanka (Bouillon et al., 2004). Cy19:0 comprised up to $14.8 \%$ of the total PLFA pool in the mangrove sediments and was well correlated with the relative abundance of the SR markers 10Me16:0 (Fig. 5C) and i17:0 (figure not shown). Again, cy19:0 was distinctly less abundant in the seagrass sediments. Although these correlations make it tempting to suggest that cy19:0 is a potential marker for SR, this PLFA can also be abundant in terrestrial soils (e.g. Burke et al., 2003) and is therefore not restricted to sulfate reducers. 


\subsection{Carbon substrates for sedimentary bacteria}

The $\delta^{13} C_{\text {PLFA }}$ data from the mangrove sediment cores show a markedly higher variability than the $\delta^{13} \mathrm{C}_{\mathrm{TOC}}$ data (Fig. 3). Part of this variability in $\delta^{13} \mathrm{C}_{\mathrm{PLFA}}$ is horizontal (i.e. between-site) and does not correlate well with $\delta^{13} \mathrm{C}_{\mathrm{TOC}}$. The absence of a clear correlation is likely to be linked to the fairly small range of $\delta^{13} \mathrm{C}_{\mathrm{TOC}}$ in the present study, since a comparison of different mangrove sites in India and Sri Lanka, covering a wider range of $\delta^{13} \mathrm{C}_{\mathrm{TOC}}$, did reveal a clear correlation between $\delta^{13} \mathrm{C}_{\mathrm{TOC}}$ and $\delta^{13} \mathrm{C}_{\mathrm{PLFA}}$ (Bouillon et al., 2004). Moreover, a significant part of the $\delta^{13} C_{\text {PLFA }}$ variability is related to depthwise trends, where in comparison to the small decrease in $\delta^{13} \mathrm{C}_{\mathrm{TOC}}$ with depth (approximately $-0.7 \%$ ), the PLFA $\delta^{13} \mathrm{C}$ values show a much more pronounced decrease, typically reaching $\sim-4 \%$ o between the surface layer and the $4-10 \mathrm{~cm}$ section (exemplified for $\mathrm{i}+\mathrm{a} 15: 0$ and 16:0 in Figs. 4A and 4B). These patterns are quite similar to those we described earlier in mangrove sediments from India and Sri Lanka (Bouillon et al., 2004), although the depthwise decrease in $\delta^{13} \mathrm{C}_{i+a 15: 0}$ was on average less pronounced (averaging $-1.8 \pm 1.9 \%$ o, $n=8$, between the $0-1$ and $4-10 \mathrm{~cm}$ layer) in the previous dataset. Assuming that the degree of fractionation for $i+a 15: 0$ is not markedly different under oxic and anoxic conditions (see Boschker et al., 1999), such a depthwise trend in $\delta^{13} C_{i+a 15: 0}$ could be the result of a selective use of ${ }^{13} \mathrm{C}$-enriched $\mathrm{C}$ sources in the surface layer(s). Microphytobenthos, with $\delta^{13} \mathrm{C}$ values ranging typically between -24 and $-14 \%$ (e.g. Bouillon et al., 2002; Connolly, 2003), and imported seagrass-derived material $\left(\delta^{13} \mathrm{C}\right.$ in this system ranging between -19.7 and $-10.7 \%$ o, Hemminga et al., 1994 and this study) are both potential candidates. Field experiments using ${ }^{13} \mathrm{C}$-spiked bicarbonate to label benthic primary producers in the seaward Sonneratia site have shown a rapid transfer of microphytobenthos $\mathrm{C}$ into certain bacterial PLFA in the surface layers (Bouillon, unpublished data), which is one argument to favor the former as a selectively used substrate - in particular considering the more labile nature of this source. However, in view of the limited data on isotopic fractionation between the source $\mathrm{C}$ and bacterial PLFA, small differences in fractionation under oxic and anoxic conditions cannot be excluded.

$\delta^{13} \mathrm{C}$ values of $\mathrm{i}+\mathrm{a} 15: 0$ in the seagrass sediments correlated fairly well with sediment $\delta^{13} \mathrm{C}_{\mathrm{TOC}}$ (Figs. 3 and $6 \mathrm{~A}$, $\left.\mathrm{R}^{2}=0.78, \mathrm{p}<0.001\right)$, their relationship with seagrass $\delta^{13} \mathrm{C}$ was more scattered (Fig. 6B). If we assume a fractionation of $-5.6 \pm 1.8 \%$ o between the substrate and $i+a 15: 0$ (as determined experimentally by Boschker et al., 1999), it is clear that in general, bacterial communities rely more on the available bulk sediment organic $\mathrm{C}$ rather than depending only on local seagrass material (Figs. 6A and 6B) - none of our data fall within the range expected when seagrasses would be the sole $\mathrm{C}$ source. As our elemental and $\delta^{13} \mathrm{C}$ data indicate a large contribution of mangrove-derived $\mathrm{C}$ to the seagrass bed sediments (roughly estimated at $21-70 \%$ of the sediment
TOC pool, see above), this implies that a significant part of benthic mineralization in the seagrass beds is sustained by allochtonous carbon trapped in the seagrass beds. Taking the same two potential sources as end members (i.e. the average values for mangroves and the site-specific $\delta^{13} \mathrm{C}$ value for pooled seagrass leaves), we can calculate that seagrass material sustains $26-84 \%$ of benthic mineralization, and this contribution correlates well with the estimated contribution of seagrass $C$ to the TOC pool $\left(R^{2}=0.60, p<0.05\right.$, slope not significantly different from 1). As mentioned in Sect. 4.1, we must stress that these numbers must be interpreted with caution, as our simplified 2-end mixing model does not take into account possible contributions by phytoplankton, microphytobenthos or seagrass epiphytes. Moreover, including the observed (small) shifts in $\delta^{13} \mathrm{C}$ during degradation (typically $<2 \%$ o) in our model would slightly affect the outcome of our calculations. However, because literature data on the degree and direction of shifts are not unequivocal and do not allow us to constrain this factor well, we have therefore not included it. As an example, however, a $1 \%$ o shift towards more enriched $\delta^{13} \mathrm{C}$ values for both end-members would raise the estimated contribution of mangrove $\mathrm{C}$ by approximately $7 \%$. However, the main purpose of our simplified 2 end-member approach is to show that (i) a significant part of the seagrass sediment TOC pool is likely to have been imported to the seagrass beds, and (ii) that the relative importance of these allochtonous $\mathrm{C}$ sources to mineralization is largely proportional to its availability in the TOC pool

A comparison of the PLFA isotope data gathered in this study and available literature data (Boschker et al., 2000; Holmer et al., 2001; Jones et al., 2003) on seagrass systems is presented in Figs. 6A and 6B. These data clearly demonstrate that in many cases, a close link between seagrasses and bacterial communities is not present (note that on Fig. 6B such close coupling between seagrass $\mathrm{C}$ and bacteria is indicated by data that plot close to the dashed line). Several hypotheses have been proposed to explain the absence or presence of a tight link between bacteria and seagrassess: (i) the degree of coupling between seagrasses and benthic bacterial communities relies on the relative importance of seagrass and other sources to the sediment TOC pool (as suggested in Jones et al., 2003). Although the $\delta^{13} \mathrm{C}_{\mathrm{PLFA}}$ data generally agree better with a dominant reliance on sediment TOC than on local seagrasses (Figs. 6A and, 6B), this hypothesis does not fit with the data in Holmer et al. (2001, 2004). (ii) Holmer et al. (2001), who provided the first data from the tropics, suggested that there could be a distinct difference between tropical and temperate systems, the former being characterized by generally lower TOC concentrations and hence, a larger relience on local seagrass material (e.g. through root exudates). However, since their data contrast with this study, such a hypothesis is equally insufficient. The fact that other driving factors must be considered is confirmed in the recent study of Holmer et al. (2004) on different Mediterranean seagrass meadows, where bacteria were found to obtain the 
bulk of their $\mathrm{C}$ requirements from seagrasses in pristine sites, but other sources (in particular, sestonic material) contributed significantly in anthropogenically impacted sites. Their calculations indicated that the relative contribution of seagrasses to bacterial communities was typically higher than the contribution of seagrass $C$ to the sediment TOC pool. (iii) Lastly, it has been suggested that various seagrass species may exhibit a different degree of root exudation, with some studies indicating high release rates of organic carbon from roots and others finding no evidence for root exudation (see Holmer et al., 2001 for a discussion). ${ }^{13} \mathrm{C}$-tracer experiments to directly follow the transfer of photosynthetically fixed seagrass $\mathrm{C}$ to sedimentary bacteria with different seagrass species (analogous to those presented in Boschker et al., 2000) could provide interesting data to verify the extent to which this influences the degree of relience on seagrass $\mathrm{C}$.

In conclusion, even though we are far from understanding the reasons for the observed patterns in the link between seagrasses, external $\mathrm{C}$ inputs, and the corresponding sources for bacterial communities (Figs. 6A and 6B), it is clear that large site- and/or species-specific differences exist in the degree to which bacterial communities rely on seagrass $C$, and this dependency is not explained merely by the relative contribution of seagrass and other $\mathrm{C}$ sources to the sediment.

A compilation of seagrass and sediment $\delta^{13} \mathrm{C}$ data (Fig. 7, see also Kennedy et al., 2004) indicates that in a majority of sites, $\delta^{13} \mathrm{C}_{\mathrm{TOC}}$ in seagrass beds is significantly lower than that of the dominant seagrass vegetation, indicating that other C sources usually contribute substantially to the sediment TOC pool. This pattern, and evidence from $\delta{ }^{13}$ C-PLFA data that, where present, these other $\mathrm{C}$ inputs may (but, not always do) contribute significantly to benthic mineralization, have important implications for the interpretation of mineralization rates measured in seagrass systems. Current compilations on the relative importance of mineralization as a fate of seagrass production have been obtained in three ways (see Duarte and Cebrián, 1996): (i) direct estimates from mass loss in decomposition experiments or $\mathrm{O}_{2}$ consumption during incubation experiments, (ii) data from community respiration rates, subsequently corrected for autotrophic respiration, and (iii) estimates based on a combination of production rates of detritus and average decomposition rates. A compilation of such data suggests that mineralization accounts for $50.3 \pm 2.0 \%$ of the overall seagrass production (Duarte and Cebrián, 1996). However, taking into account that part of the direct estimates (i.e. those obtained using $\mathrm{O}_{2}$ consumption), as well as the corrected community respiration data, inherently relate to the total $\mathrm{C}$ pool subject to mineralization - i.e. both seagrasses and external $C$ inputs- the current estimates are partially biased and should therefore represent an overestimate of the role of in situ mineralization as a fate for seagrass production. This is further exemplified by the study of Barrón et al. (2004) who found community respiration to significantly exceed local seagrass production. These data therefore stress the importance of source characteriza- tion when integrating community metabolism data into carbon budgets for particular primary producers, not only in seagrass ecosystems but likely in all coastal settings where exchange of organic matter between different habitats occurs. In our case, our approximate calculations suggest that the use of measured benthic mineralization rates without source characterization would overestimate the importance of in situ degradation to the overall fate of seagrass $\mathrm{C}$ by $15-74 \%$.

Acknowledgements. Funding for this work was provided by the Fonds voor Wetenschappelijk Onderzoek (FWO-Vlaanderen, contract G.0118.02). S. B. and T. M. are postdoctoral fellows with the FWO-Vlaanderen. We are grateful to I. De Mesel and A. V. Borges for their help during sample collection, and to J. G. Kairo and J. Bosire for their excellent help in organising the logistics during fieldwork. H. T. S. Boschker and M. Holmer kindly provided their raw data on sediment, seagrass and PLFA stable isotope ratios, and $\mathrm{H}$. Kennedy provided some additional literature data on seagrass and sediment $\delta^{13} \mathrm{C}$. We are grateful to D. Gillikin, and two anonymous referees for their insightful and constructive comments on an earlier version of this manuscript.

Edited by: S. W. A. Naqvi

\section{References}

Barrón, C., Marbà, N., Terrados, J., Kennedy, H., and Duarte, C. M.: Community metabolism and carbon budget along a gradient of seagrass (Cymodocea nodosa) colonization, Limnol. Oceanogr. 49, 1642-1651, 2004.

Boschker, H. T. S., de Brouwer, J. F. C., and Cappenberg, T. E.: The contribution of macrophyte- derived organic matter to microbial biomass in salt-marsh sediments: stable carbon isotope analysis of microbial biomarkers, Limnol. Oceanogr., 44, 309-319, 1999.

Boschker, H. T. S., Wielemaker, A., Schaub, B. E. M., and Holmer, M.: Limited coupling of macrophyte production and bacterial carbon cycling in the sediments of Zostera spp. meadows, Mar. Ecol. Prog. Ser., 203, 181-189, 2000.

Bouillon, S., Dahdouh-Guebas, F., Rao, A. V. V. S., Koedam, N., and Dehairs, F.: Sources of organic carbon in mangrove sediments: variability and possible implications for ecosystem functioning, Hydrobiologia, 495, 33-39, 2003.

Bouillon, S., Koedam, N., Raman, A. V., and Dehairs, F.: Primary producers sustaining macroinvertebrate consumers in intertidal mangrove forests, Oecologia, 130, 441-448, 2002.

Bouillon, S., Moens, T., Koedam, N., Dahdouh-Guebas, F., Baeyens, W., and Dehairs, F.: Interecosystem variability in the origin of carbon substrates for bacterial communities in mangrove sediments, FEMS Microbiol. Ecol., 49, 171-179, 2004.

Burke, R. A., Molina, M., Cox, J. E., Osher, L. J., and Piccolo, M. C.: Stable carbon isotope ratio and composition of microbial fatty acids in tropical soils, J. Environm. Qual., 32, 198-206, 2003.

Canfield, D. E. and Des Marais, D. J.: Aerobic sulfate reduction in microbial mats, Science, 251, 1471-1473, 1991.

Cebrián, J.: Variability and control of carbon consumption, export, and accumulation in marine communities, Limnol. Oceanogr., 47, 11-22, 2002. 
Connolly, R. M.: Differences in trophodynamics of commercially important fish between artificial waterways and natural coastal wetlands, Estuar. Coast Shelf Sci., 58, 929-936, 2003.

Coppejans, E., Beeckman, H., and De Wit, M.: The seagrass and associated macroalgal vegetation of Gazi bay (Kenya), Hydrobiologia, 247, 59-75, 1992

Dauby, P.: The stable carbon isotope ratios in benthic food webs of the Gulf of Calvi, Corsica, Cont. Shelf Res., 9, 181-195, 1989.

Dauby, P., Khomsi, A., and Bouquegneau, J. M.: Trophic relationships within intertidal communities of the Brittany coast: a stable carbon isotope analysis, J. Coastal Res., 14, 1202-1212, 1998.

Duarte, C. M. and Cebrián, J.: The fate of marine autotrophic production, Limnol. Oceanogr., 41, 1758-1766, 1996.

Ehleringer, J. R., Buchmann, N., and Flanagan, L. B.: Carbon isotope ratios in belowground carbon cycle processes, Ecol. Appl., 10, 412-422, 2000.

Fry, B.: ${ }^{13} \mathrm{C} /{ }^{12} \mathrm{C}$ ratios and the trophic importance of algae in Florida Syringodium filiforme seagrass meadows, Mar. Biol., 79, 11-19, 1984.

Fry, B., Lutes, R., Northam, M., and Parker, P. L.: A ${ }^{13} \mathrm{C} /{ }^{12} \mathrm{C}$ comparison of food webs in a Caribbean seagrass meadow and coral reefs, Aquat. Bot., 14, 389-398, 1982.

Fry, B., Scalan, R. S., and Parker, P. L.: Stable carbon isotope evidence for two sources of organic matter in coastal sediments: seagrass and plankton, Geochim Cosmochim Acta, 41, 18751877, 1977.

Fry, B., Scalan, R. S., and Parker, P. L.: ${ }^{13} \mathrm{C} /{ }^{12} \mathrm{C}$ ratios in marine food webs of the Torres Strait, Queensland, Austr. J. Mar. Freshwater Res., 34, 707-715, 1983.

Gacia, E., Duarte, C. M., and Middelburg, J. J.: Carbon and nutrient deposition in a Mediterranean seagrass (Posidonia oceanica) meadow, Limnol. Oceanogr., 47, 23-32, 2002.

Gattuso, J .P., Frankignoulle, M., and Wollast, R.: Carbon and carbonate metabolism in coastal aquatic ecosystems, Annu. Rev. Ecol. Syst., 29, 405-434, 1998.

Harrigan, P., Zieman, J. C., and Macko, S. A.: The base of nutritional support for the grey snapper (Lutjanus griseus): an evaluation based on a combined stomach content and stable isotope analysis, Bull. Mar. Sci., 44, 65-77, 1989.

Hemminga, M. A., Slim, F. J., Kazungu, J., Ganssen, G. M., Nieuwenhuize, J., and Kruyt, N.M.: Carbon outwelling from a mangrove forest with adjacent seagrass beds and coral reefs (Gazi bay, Kenya), Mar. Ecol. Prog. Ser., 106, 291-301, 1994.

Hemminga, M. A., Gwada, P., Slim, F. J., de Koeyer, P., and Kazungu, J.: Leaf production and nutrient contents of the seagrass Thalassodendron ciliatum in the proximity of a mangrove forest (Gazi Bay, Kenya), Aquat. Bot., 50, 159-170, 1995.

Holmer, M., Andersen, F. O., Nielsen, S. L., and Boschker, H. T. S.: The importance of mineralization based on sulfate reduction for nutrient regeneration in tropical seagrass sediments, Aquat. Bot., $71,1-17,2001$
Holmer, M., Duarte, C. M., Boschker, H. T. S., and Barrón, C.: Carbon cycling and bacterial carbon sources in pristine and impacted Mediterranean seagrass sediments, Aquat. Microb. Ecol., 36, 227-237, 2004.

Jones, W. B., Cifuentes, L. A., and Kaldy, J. E.: Stable carbon isotope evidence for coupling between sedimentary bacteria and seagrasses in a sub-tropical lagoon, Mar. Ecol. Prog. Ser., 255, $15-25,2003$.

Kennedy, H., Gacia, E., Kennedy, D. P., Papadimitriou, S., and Duarte, C. M.: Organic carbon sources to SE Asian coastal sediments, Estuar. Coast. Shelf. Sci., 60, 59-68, 2004.

Kennedy, H., Richardson, C., and Duarte, C. M.: Diet and association of Pontonia pinnophylax occurring in Pinna nobilis: insights from stable isotope analysis, J. Mar. Biol. Ass. UK., 81, 177-178, 2001.

Kharlamenko, V. I., Kiyashko, S. I., Imbs, A. B., and Vyskkvartzev, D. I.: Identification of food sources of invertebrates from the seagrass Zostera marina community using carbon and sulfur stable isotope ratios and fatty acid analyses, Mar. Ecol. Prog. Ser., 220, 103-117, 2001.

Kieckbusch, D. K., Koch, M. S., Serafy, J. E., and Anderson, W. T.: Trophic linkages among primary producers and consumers in fringing mangroves of subtropical lagoons, Bull. Mar. Sci., 74 271-285, 2004.

Kitheka, J. U.: Coastal tidally-driven circulation and the role of water exchange in the linkage between tropical coastal ecosystems, Estuar. Coast Shelf Sci., 45, 177-187, 1997.

Ludwig, W., Probst, J. L., and Kempe, S.: Predicting the oceanic input of organic carbon by continental erosion, Glob. Biogeochem. Cyc., 10, 23-41, 1996.

Nagelkerken, I. and van der Velde, G.: Are Caribbean mangroves important feeding grounds for juvenile reef fish from adjacent seagrass beds?, Mar. Ecol. Prog. Ser., 274, 143-151, 2004.

Ochieng, C. A. and Erftemeijer, P. L. A.: Phenology, litterfall and nutrient resorption in Avicennia marina (Forssk.) Vierh in Gazi Bay, Kenya, Trees, 16, 167-171, 2002.

Slim, F. J., Hemminga, M. A., Cocheret de la Morinière, E., and van der Velde, G.: Tidal exchange of macrolitter between a mangrove forest and adjacent seagrass beds (Gazi Bay, Kenya), Neth. J. Aquat. Ecol., 30, 119-128, 1996a.

Slim, F. J., Gwada, P. M., Kodjo, M., and Hemminga, M. A.: Biomass and litterfall of Ceriops tagal and Rhizophora mucronata in the mangrove forest of Gazi Bay, Kenya, Mar. Freshwater Res., 47, 999-1007, 1996b.

Vizzini, S., Sara, G., Michener, R. H., and Mazzola, A.: The role and contribution of the seagrass Posidonia oceanica (L.) Delille organic matter for secondary consumers as revealed grass by carbon and nitrogen stable isotope analysis, Acta Oecol., 23, 277$285,2002$.

Vizzini, S. and Mazzola, A.: The trophic structure of the pipefish community (Pisces: Syngnathi-Syngnathidae) from a western Mediterranean seagrass meadow based on stable isotope analysis) Estuaries, 27, 325-333, 2004. 